\title{
EFFECTS OF SINGLE AND MIXED SOWING OF PERENNIAL GRASS (LOLIUM PERENNE L.) WITH COOL SEASON SPECIES ON GRASS PERFORMANCE
}

\author{
BIRER, S. $^{1 *}-$ GÖKKUŞ, A. ${ }^{2}$

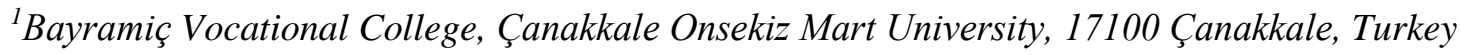 \\ ${ }^{2}$ Field Crops Department, Agricultural Faculty, Çanakkale Onsekiz Mart University, 17100 \\ Çanakkale, Turkey \\ *Corresponding author \\ e-mail: selcukbirer@comu.edu.tr
}

(Received $16^{\text {th }}$ Nov 2018; accepted $11^{\text {th }}$ Jan 2019)

\begin{abstract}
This study has been conducted in Bayramiç District of Çanakkale Province in 2017 aiming to determine the seasonal performance of single and mixed sowing of perennial grass with some cool seasoned Gramineae species. Integra of Lolium perenne, Rebel XLR of Festuca arundinacea, Dumas1 of $F$. ovina, J-5 of $F$. rubra commutata, Redskin of $F$. rubra rubra, Samantha of $F$. rubra trichophylla and Miracle of Poa pratensis were used as the experimental subjects of this study. Total biomass production and grass quality attributes were investigated based on the number of species in mixtures and seasons. Fresh and dry biomass values significantly varied correlating to the seasons. The highest biomass productions were observed in spring and autumn. The highest values for grass quality, color, width, and coverage were observed in autumn. Single-sown L. perenne plots had superior attributes as compared to the mixed-sown plots. But grass color had darker green tones with the increasing number of species in mixtures. Present findings revealed that single-sowings yielded better grasslands than that of mixedsowings and better structures were observed in autumn and spring as compared in summer. To establish quality grasslands in similar ecologies, L. perenne should be preferred and 2-3 species should be incorporated into the mixtures.
\end{abstract}

Keywords: L. perenne, mixed sowing, cool season, grass performance, grass color

\section{Introduction}

Just depending on increasing world population and developing industries, majority of the population is concentrated at city centers. People are in need of parks and recreation spots to meet their yearnings and devotion to nature (Avcıŏ̆lu, 1997; Oral and Açıkgöz, 2002). Increasing urbanization in Turkey also increased people's interest in green zones. Lawns constitute the highest green zones of urban life. These zones are commonly established with the aid of architectural techniques as green covers for visual and esthetic purposes. They appeal to the eye and offer mental comfort, thus constitute a resting place for people (Avcioğlu, 1997). Besides, lawns are natural oxygen depots of the cities, thus they purify city air and regulate precipitation regimes (Oral and Açıkgöz, 2002). Such green zones are also significant in mitigation the impact of climate change through absorbing sunrays and in reduction of pollution through absorbing environmental dust particles (Avcioğlu, 1997). Maintenance of football pitches over which various sport activities are performed is a quite troublesome and difficult job requiring expertise. To establish high-quality long-lasting grasslands with attractive color, well cover ratio and rate, fast regeneration rates, resistant to pests, diseases and negative conditions and requiring less maintenance and mowing, the grass species to be used, their characteristics and adaptation capacities to the places they used should 
throughly be investigated and appropriate ones should be selected meticulously (Avcioğlu, 1997). Grasslands are green spots composed of plant species covering the entire ground surface with a uniform appearance and able to be continuously mowed. According to data of the World Health Organization (WHO), the amount of green spots per capita should be at least $9 \mathrm{~m}^{2}$. While such an area is around $8-12 \mathrm{~m}^{2}$ in EU countries, it is only $2 \mathrm{~m}^{2}$ in Turkey. The amount of green spots open to public in metropolitan cities of New York, Paris, London, Rio de Janeiro and İstanbul was respectively reported as 14\%, 9.4\%,38.4\%, 29\% and 1.5\% (Sözen et al., 1991; Önder and Polat, 2012).

In this study, the plant species of Lolium, Festuca and Poa, Lolium perenne, F. ovina, F. rubra commutata, F. rubra rubra, F. rubra trichophylla and Poa pratensis plant species of the genus Lolium, Festuca and Poa have been used in the studies that was carried out in order to create grass areas in the ecology of Mediterranean countries. It was aimed to determine the performance and quality characteristics of different grass using single as well as mix-cropping systems.

\section{Materials and methods}

Experiments were conducted in Bayramiç town of Çanakkale province in the year 2017 (Fig. 1; see also photos in the Appendix). While the long-term annual precipitation of the experimental site was $647.5 \mathrm{~mm}$, the annual precipitation of the experimental year was $656.5 \mathrm{~mm}$. While the months November, December and January had the highest precipitation, the months July, August and September had the least precipitation. The average monthly temperature has been recorded as $16.2^{\circ} \mathrm{C}$ until the study was conducted and the average monthly temperature decreased to $16.1^{\circ} \mathrm{C}$ in 2017. While the months June, July and August were the hottest months, the months December, January and February were the coldest months. Experimental soils were clay-loam in texture. Soils were non-saline (EC $0.85 \mathrm{mS} / \mathrm{cm})$, slightly alkaline $(\mathrm{pH}$ $7.85)$, slightly limey $(0.8 \%)$, poor in organic matter $(0.78 \%)$, sufficient in available phosphorus (10.81 $\left.\mathrm{mg} \mathrm{kg}^{-1}\right)$ and potassium $\left(329.75 \mathrm{mg} \mathrm{kg}^{-1}\right)$.

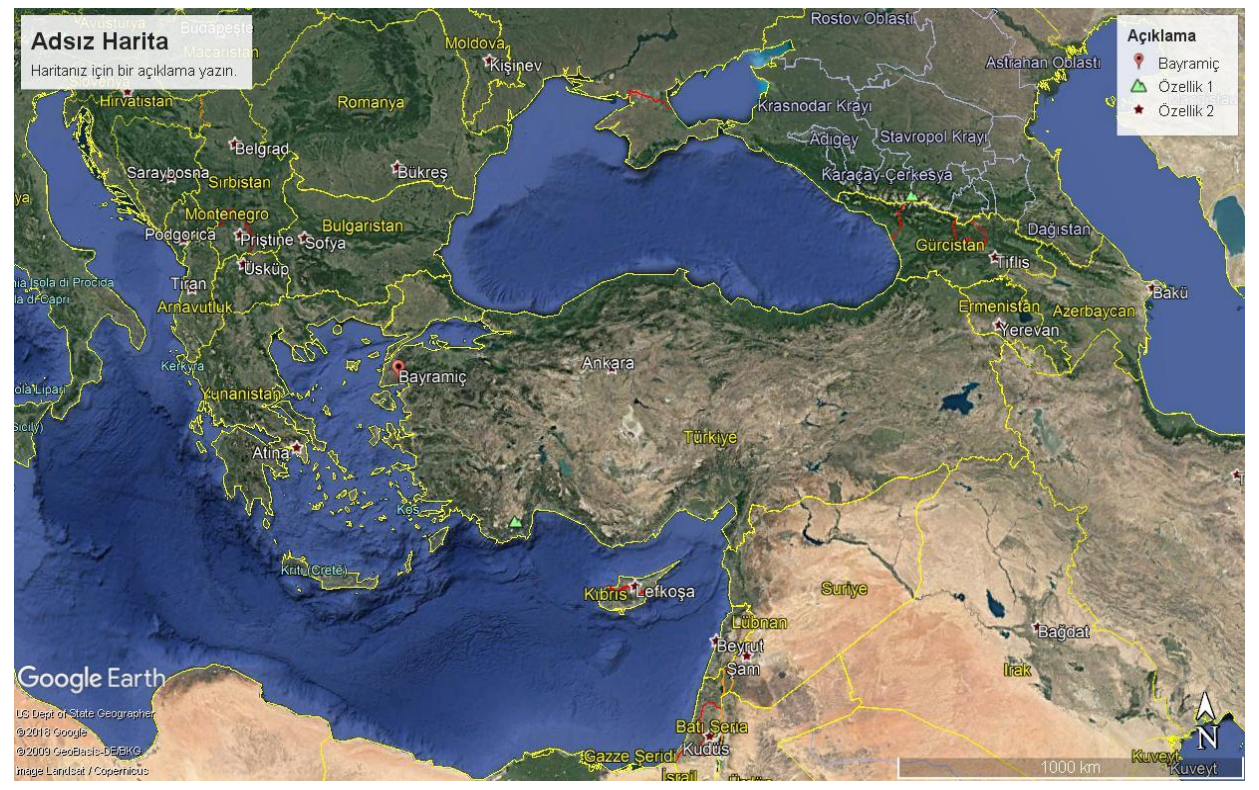

Figure 1. Study area situated in Bayramiç District of Çanakkale Province 
In the research; double, triple, quartet, fivefold, sixfold and septet mixtures of Lolium perenne Integra (LP) single and Festuca arundinacea Rebel XLR (FA), F. ovina Dumas1 (FO), F. rubra commutata J-5 (FRC), F. rubra rubra Redskin (FRR), F. rubra trichophylla Samantha (FRT) and Poa pratensis's Miracle (PP) varieties have been applied (Table 1).

Table 1. Applied mixing ratios and plants used in the experiment

\begin{tabular}{|c|c|c|c|c|c|c|c|c|}
\hline Number & Groups of plant & \multicolumn{7}{|c|}{ Mixture ratios (\%) } \\
\hline 1 & LP & 100 & - & - & - & - & - & - \\
\hline 2 & $\mathrm{FA}+\mathrm{LP}$ & 60 & 40 & - & - & - & - & - \\
\hline 3 & $\mathrm{LP}+\mathrm{FO}$ & 60 & 40 & - & - & - & - & - \\
\hline 4 & $\mathrm{LP}+\mathrm{FRC}$ & 60 & 40 & - & - & - & - & - \\
\hline 5 & $\mathrm{LP}+\mathrm{FRR}$ & 60 & 40 & - & - & - & - & - \\
\hline 6 & $\mathrm{LP}+\mathrm{FRT}$ & 60 & 40 & - & - & - & - & - \\
\hline 7 & $\mathrm{LP}+\mathrm{PP}$ & 60 & 40 & - & - & - & - & - \\
\hline 8 & $\mathrm{FA}+\mathrm{LP}+\mathrm{FO}$ & 40 & 40 & 20 & - & - & - & - \\
\hline 9 & $\mathrm{FA}+\mathrm{LP}+\mathrm{FRC}$ & 40 & 40 & 20 & - & - & - & - \\
\hline 10 & $\mathrm{FA}+\mathrm{LP}+\mathrm{FRR}$ & 40 & 40 & 20 & - & - & - & - \\
\hline 11 & $\mathrm{FA}+\mathrm{LP}+\mathrm{FRT}$ & 40 & 40 & 20 & - & - & - & - \\
\hline 12 & $\mathrm{FA}+\mathrm{LP}+\mathrm{PP}$ & 40 & 40 & 20 & - & - & - & - \\
\hline 13 & $\mathrm{FA}+\mathrm{LP}+\mathrm{FO}+\mathrm{FRC}$ & 30 & 30 & 20 & 20 & - & - & - \\
\hline 14 & $\mathrm{FA}+\mathrm{LP}+\mathrm{FO}+\mathrm{FRR}$ & 30 & 30 & 20 & 20 & - & - & - \\
\hline 15 & $\mathrm{FA}+\mathrm{LP}+\mathrm{FO}+\mathrm{FRT}$ & 30 & 30 & 20 & 20 & - & - & - \\
\hline 16 & $\mathrm{FA}+\mathrm{LP}+\mathrm{FO}+\mathrm{PP}$ & 30 & 30 & 20 & 20 & - & - & - \\
\hline 17 & $\mathrm{FA}+\mathrm{LP}+\mathrm{FRC}+\mathrm{FRR}$ & 30 & 30 & 20 & 20 & - & - & - \\
\hline 18 & $\mathrm{FA}+\mathrm{LP}+\mathrm{FRC}+\mathrm{FRT}$ & 30 & 30 & 20 & 20 & - & - & - \\
\hline 19 & $\mathrm{FA}+\mathrm{LP}+\mathrm{FRC}+\mathrm{PP}$ & 30 & 30 & 20 & 20 & - & - & - \\
\hline 20 & $\mathrm{FA}+\mathrm{LP}+\mathrm{FRR}+\mathrm{FRT}$ & 30 & 30 & 20 & 20 & - & - & - \\
\hline 21 & $\mathrm{FA}+\mathrm{LP}+\mathrm{FRR}+\mathrm{PP}$ & 30 & 30 & 20 & 20 & - & - & - \\
\hline 22 & $\mathrm{FA}+\mathrm{LP}+\mathrm{FRT}+\mathrm{PP}$ & 30 & 30 & 20 & 20 & - & - & - \\
\hline 23 & $\mathrm{FA}+\mathrm{LP}+\mathrm{FO}+\mathrm{FRC}+\mathrm{FRR}$ & 25 & 25 & 20 & 15 & 15 & - & - \\
\hline 24 & $\mathrm{FA}+\mathrm{LP}+\mathrm{FO}+\mathrm{FRC}+\mathrm{FRT}$ & 25 & 25 & 20 & 15 & 15 & - & - \\
\hline 25 & $\mathrm{FA}+\mathrm{LP}+\mathrm{FO}+\mathrm{FRR}+\mathrm{FRT}$ & 25 & 25 & 20 & 15 & 15 & - & - \\
\hline 26 & $\mathrm{FA}+\mathrm{LP}+\mathrm{FRC}+\mathrm{FRR}+\mathrm{FRT}$ & 25 & 25 & 20 & 15 & 15 & - & - \\
\hline 27 & $\mathrm{FA}+\mathrm{LP}+\mathrm{FO}+\mathrm{FRC}+\mathrm{PP}$ & 25 & 25 & 20 & 15 & 15 & - & - \\
\hline 28 & $\mathrm{FA}+\mathrm{LP}+\mathrm{FO}+\mathrm{FRR}+\mathrm{PP}$ & 25 & 25 & 20 & 15 & 15 & - & - \\
\hline 29 & $\mathrm{FA}+\mathrm{LP}+\mathrm{FRC}+\mathrm{FRR}+\mathrm{PP}$ & 25 & 25 & 20 & 15 & 15 & - & - \\
\hline 30 & $\mathrm{FA}+\mathrm{LP}+\mathrm{FO}+\mathrm{FRT}+\mathrm{PP}$ & 25 & 25 & 20 & 15 & 15 & - & - \\
\hline 31 & $\mathrm{FA}+\mathrm{LP}+\mathrm{FRC}+\mathrm{FRT}+\mathrm{PP}$ & 25 & 25 & 20 & 15 & 15 & - & - \\
\hline 32 & $\mathrm{FA}+\mathrm{LP}+\mathrm{FRR}+\mathrm{FRT}+\mathrm{PP}$ & 25 & 25 & 20 & 15 & 15 & - & - \\
\hline 33 & $\mathrm{FA}+\mathrm{LP}+\mathrm{FO}+\mathrm{FRC}+\mathrm{FRR}+\mathrm{FRT}$ & 30 & 30 & 10 & 10 & 10 & 10 & - \\
\hline 34 & $\mathrm{FA}+\mathrm{LP}+\mathrm{FO}+\mathrm{FRC}+\mathrm{FRR}+\mathrm{PP}$ & 30 & 30 & 10 & 10 & 10 & 10 & - \\
\hline 35 & $\mathrm{FA}+\mathrm{LP}+\mathrm{FO}+\mathrm{FRC}+\mathrm{FRT}+\mathrm{PP}$ & 30 & 30 & 10 & 10 & 10 & 10 & - \\
\hline 36 & $\mathrm{FA}+\mathrm{LP}+\mathrm{FO}+\mathrm{FRR}+\mathrm{FRT}+\mathrm{PP}$ & 30 & 30 & 10 & 10 & 10 & 10 & - \\
\hline 37 & $\mathrm{FA}+\mathrm{LP}+\mathrm{FRC}+\mathrm{FRR}+\mathrm{FRT}+\mathrm{PP}$ & 30 & 30 & 10 & 10 & 10 & 10 & - \\
\hline 38 & $\mathrm{FA}+\mathrm{LP}+\mathrm{FO}+\mathrm{FRC}+\mathrm{FRR}+\mathrm{FRT}+\mathrm{PP}$ & 25 & 25 & 10 & 10 & 10 & 10 & 10 \\
\hline
\end{tabular}


Experiments were conducted over 114 plots $\left(1 \mathrm{~m} \times 2 \mathrm{~m}=2 \mathrm{~m}^{2}\right)$ in randomized blocks design with 3 replications. Sowing norm in the shape of seed $/ \mathrm{m}^{2}$. Plots were 20 $\mathrm{cm}$ apart and blocks were $40 \mathrm{~cm}$ apart from each other. Before sowing, nitrogen $(\mathrm{N})$, phosphorus $\left(\mathrm{P}_{2} \mathrm{O}_{5}\right)$ and potassium $\left(\mathrm{K}_{2} \mathrm{O}\right)$ were applied to soils as composed fertilizer (15.15.15) as to have $10 \mathrm{~g} / \mathrm{m}^{2}$ on 19.10.2015. Ammonium sulphate was also applied to each plot on 02.05.2016 and 17.10.2016 as to have $5 \mathrm{~g} / \mathrm{m}^{2} \mathrm{~N}$. Green and dry biomass along with grass quality according to Sills and Carrow (1983), Mehall et al., (1983) and Avcioğlu (1997), grass color, width and coating ratios have been determined according to Spangenberg et al. (1986), Wenher et al. (1988), Goatley et al. (1994) and Avcioğlu (1997). Resultant data were subjected to statistical analyses in accordance with randomized blocks split plots experimental design. Means were compared with Duncan's multiple comparison test (Düzgüneş et al., 1987).

\section{Results}

\section{Fresh and dry biomass}

While fresh biomass of grasslands significantly varied with the seasons, effects of number of species in mixtures and number of species $\mathrm{x}$ season interactions did not have significant effects on fresh biomass values. The highest fresh biomass $\left(459.0 \mathrm{~g} / \mathrm{m}^{2}\right)$ was obtained from spring and the least fresh biomass $\left(314.9 \mathrm{~g} / \mathrm{m}^{2}\right)$ was obtained from summer season. Based on the number of species in mixtures, fresh biomass values varied between $347.4-427.9 \mathrm{~g} / \mathrm{m}^{2}$. Despite the insignificant differences between them, single-sown and senary mixtures of $L$. perenne had slightly greater fresh biomass quantities (Table 2).

Table 2. Number of species in the mixture and green mass amounts of grass area according to season $\left(\mathrm{g} / \mathrm{m}^{2}\right)$

\begin{tabular}{c|c|c|c|c}
\hline Number of species & Spring & Summer & Autumn & Mean \\
\hline 1 & 504.7 & 318.8 & 450.8 & 424.7 \\
2 & 424.7 & 341.4 & 371.7 & 379.3 \\
3 & 442.5 & 311.6 & 366.4 & 371.5 \\
4 & 440.2 & 295.6 & 364.6 & 366.8 \\
5 & 460.7 & 311.9 & 412.9 & 395.1 \\
6 & 517.7 & 321.4 & 444.6 & 427.9 \\
7 & 422.7 & 303.3 & 316.3 & 347.4 \\
\hline Mean & $459.0 \mathrm{a}$ & $314.9 \mathrm{c}$ & $388.8 \mathrm{~b}$ & - \\
\hline Significance & $\mathrm{P}_{\text {number of species }}=0.1795, \mathrm{P}_{\text {season }}=0.0001, \mathrm{P}_{\text {number of species*eason }}=0.9586$ \\
\hline
\end{tabular}

While the dry biomass of single-sown and mixtures of $L$. perenne did not significantly vary relative to the number subject of species in mixtures, but significant differences were observed between the dry biomass values of the seasons. Based on number of species in mixtures, dry biomass values varied between $97.3-110.9 \mathrm{~g} / \mathrm{m}^{2}$. On the other hand, while the highest dry biomass values were observed in spring $\left(112.6 \mathrm{~g} / \mathrm{m}^{2}\right)$ and autumn $\left(111.9 \mathrm{~g} / \mathrm{m}^{2}\right)$, plants had less dry biomass in summer $\left(87.0 \mathrm{~g} / \mathrm{m}^{2}\right)($ Table 3$)$. 
Birer - Gökkuş: Effects of single and mixed sowing of perennial grass (Lolium perenne L.) with cool season species on grass performance

$-591-$

Table 3. Number of species in the mixture and dry mass of grass area according to the season $\left(\mathrm{g} / \mathrm{m}^{2}\right)$

\begin{tabular}{c|c|c|c|c}
\hline Number of species & Spring & Summer & Autumn & Mean \\
\hline 1 & 121.4 & 86.8 & 124.3 & 110.9 \\
2 & 107.2 & 94.4 & 111.7 & 104.4 \\
3 & 107.4 & 83.6 & 105.7 & 98.9 \\
4 & 109.3 & 82.9 & 107.7 & 100.0 \\
5 & 112.9 & 86.4 & 115.9 & 105.0 \\
6 & 122.1 & 86.0 & 122.1 & 110.0 \\
7 & 107.9 & 88.6 & 95.6 & 97.3 \\
\hline Mean & 112.6 a & $87.0 \mathrm{~b}$ & $111.9 \mathrm{a}$ & - \\
\hline Significance & $\mathrm{P}_{\text {number of species }}=0.2220 \mathrm{P}_{\text {season }}=0.0001, \mathrm{P}_{\text {number of species*season }}=0.8270$ \\
\hline
\end{tabular}

\section{Grass quality}

In order to determine the quality values of pre-harvest quality in each plot that applied by Sills and Carrow (1983) and Mehall et al. (1983), and the quality values were also determined according to the scale of 1-9 (1: worst, 9: best) with regard to the uniformity, frequency and cleanliness of the grass that described by Avc1oğlu (1997). While number of species in L. perenne mixtures and seasons had significant effects on grass quality, the effects of interactions were not found to be significant. The best quality (with a score of 9.0 points) was achieved in autumn and the poorest quality (with a score of 7.4 points) was observed in spring. Slight decreases were observed in quality scores with the increasing number of species in mixtures (Table 4).

Table 4. Grass quality based on number of species in mixtures and seasons

\begin{tabular}{c|c|c|c|c}
\hline Number of species & Spring & Summer & Autumn & Mean \\
\hline 1 & 7.7 & 8.3 & 9.0 & $8.3 \mathrm{a}$ \\
2 & 7.5 & 8.1 & 9.0 & $8.2 \mathrm{ab}$ \\
3 & 7.5 & 8.1 & 8.9 & $8.2 \mathrm{ab}$ \\
4 & 7.2 & 8.1 & 9.0 & $8.1 \mathrm{~b}$ \\
5 & 7.2 & 7.1 & 9.0 & $8.1 \mathrm{~b}$ \\
6 & 7.4 & 8.2 & 8.8 & $8.1 \mathrm{~b}$ \\
7 & 7.0 & 8.1 & 9.0 & $8.0 \mathrm{~b}$ \\
\hline Mean & $7.4 \mathrm{c}$ & $8.1 \mathrm{~b}$ & $9.0 \mathrm{a}$ & - \\
\hline Significance & $\mathrm{P}_{\text {number of species }}=0.0310, \mathrm{P}_{\text {season }}=0.0001, \mathrm{P}_{\text {number of species* } * \text { season }}=0.0705$ \\
\hline
\end{tabular}

\section{Grass color}

In each plot, the color of the grass was determined in the period in which the harvesting was not done in order to determine the color of the plot periodically applied by Spangenberg et al. (1986); Wenher et al. (1988) and Goatley et al. (1994), and the color of the grass has also been determined according to the harvesting scale of 1-9 (1: yellow, 9: dark green) as indicated by Avcioğlu (1997). Grass color 
significantly varied with number of species in mixtures, seasons and their interactions. The best grass color (7.34) was observed in autumn and it was followed by summer (6.30) and spring (3.68). Increasing number of species in mixtures improved grass color (Table 5).

Table 5. Grass color based on number of species in mixtures and seasons

\begin{tabular}{c|c|c|c|c}
\hline Number of species & Spring & Summer & Autumn & Mean \\
\hline 1 & $3.70 \mathrm{~g}$ & $6.53 \mathrm{e}$ & $7.00 \mathrm{~d}$ & $5.74 \mathrm{BC}$ \\
2 & $3.67 \mathrm{~g}$ & $6.13 \mathrm{f}$ & $7.13 \mathrm{~cd}$ & $5.64 \mathrm{C}$ \\
3 & $3.70 \mathrm{~g}$ & $6.23 \mathrm{f}$ & $7.30 \mathrm{bc}$ & $5.74 \mathrm{BC}$ \\
4 & $3.67 \mathrm{~g}$ & $6.17 \mathrm{f}$ & $7.30 \mathrm{bc}$ & $5.71 \mathrm{BC}$ \\
5 & $3.63 \mathrm{~g}$ & $6.37 \mathrm{ef}$ & $7.37 \mathrm{bc}$ & $5.79 \mathrm{~B}$ \\
6 & $3.70 \mathrm{~g}$ & $6.37 \mathrm{ef}$ & $7.40 \mathrm{~b}$ & $5.82 \mathrm{~B}$ \\
7 & $3.70 \mathrm{~g}$ & $6.30 \mathrm{ef}$ & $7.90 \mathrm{a}$ & $5.97 \mathrm{~A}$ \\
\hline Mean & $3.68 \mathrm{C}$ & $6.30 \mathrm{~B}$ & $7.34 \mathrm{~A}$ & - \\
\hline Significance & $\mathrm{P}_{\text {number of species }}=0.0021, \mathrm{P}_{\text {season }}=0.0001, \mathrm{P}_{\text {number of species*season }}=0.0001$ \\
\hline
\end{tabular}

\section{Grass width}

While number of species had significant effects on grass width, the effects of seasons and interactions were not found to be significant. Grass widths decreased with increasing number of species in mixtures. The highest grass width $(3.98 \mathrm{~mm})$ was obtained from single-sown $L$. perenne plots. Based on seasons, grass widths varied between 3.34-390 mm (Table 6).

Table 6. Grass width based on number of species in mixtures and seasons (mm)

\begin{tabular}{c|c|c|c|c}
\hline Number of species & Spring & Summer & Autumn & Mean \\
\hline 1 & 3.97 & 3.97 & 4.00 & $3.98 \mathrm{~A}$ \\
2 & 3.73 & 3.83 & 3.87 & $3.81 \mathrm{~B}$ \\
3 & 3.30 & 3.37 & 3.40 & $3.36 \mathrm{C}$ \\
4 & 3.17 & 3.27 & 3.27 & $3.23 \mathrm{CD}$ \\
5 & 3.13 & 3.13 & 3.20 & $3.16 \mathrm{D}$ \\
6 & 3.13 & 3.13 & 3.17 & $3.14 \mathrm{D}$ \\
7 & 3.93 & 3.03 & 3.03 & $3.00 \mathrm{E}$ \\
\hline Mean & 3.34 & 3.90 & 3.42 & - \\
\hline Significance & $\mathrm{P}_{\text {numbe of species }}=0.0001, \mathrm{P}_{\text {season }}=0.1744, \mathrm{P}_{\text {numbe of species*season }}=0.9999$ \\
\hline
\end{tabular}

\section{Grass coverage}

Grass coverage was significantly greater in autumn (8.96) than in the other seasons. The lowest coverage (8.29) was observed in summer. Number of species in mixtures did not yield significant variations in grass coverage and the values varied between 8.468.68 (Table 7). 
Table 7. Grass coverage based on number of species in mixtures and seasons

\begin{tabular}{|c|c|c|c|c|}
\hline Number of species & Spring & Summer & Autumn & Mean \\
\hline 1 & $8.10 \mathrm{~b}$ & $8.30 \mathrm{~b}$ & $9.00 \mathrm{a}$ & 8.46 \\
\hline 2 & $8.10 \mathrm{~b}$ & $8.30 \mathrm{~b}$ & $9.00 \mathrm{a}$ & 8.46 \\
\hline 3 & $8.77 \mathrm{a}$ & $8.27 \mathrm{~b}$ & $8.83 \mathrm{a}$ & 8.62 \\
\hline 4 & $8.73 \mathrm{a}$ & $8.30 \mathrm{~b}$ & $9.00 \mathrm{a}$ & 8.67 \\
\hline 5 & $8.77 \mathrm{a}$ & $8.30 \mathrm{~b}$ & $9.00 \mathrm{a}$ & 8.68 \\
\hline 6 & $8.77 \mathrm{a}$ & $8.27 \mathrm{~b}$ & $8.90 \mathrm{a}$ & 8.64 \\
\hline 7 & $8.77 \mathrm{a}$ & $8.30 \mathrm{~b}$ & $9.00 \mathrm{a}$ & 8.68 \\
\hline Mean & $8.57 \mathrm{~B}$ & $8.29 \mathrm{C}$ & $8.96 \mathrm{~A}$ & - \\
\hline Significance & \multicolumn{4}{|c|}{$P_{\text {number of species }}=0.0484, P_{\text {season }}=0.0001, P_{\text {number of species } * \text { season }}=0.0033$} \\
\hline
\end{tabular}

\section{Discussion}

The species used in formation of grasslands are cool season species. Cool season species exhibit their best growth and development in spring (Miller, 1984). Plants then exhibit regrowth in autumn with cooling weathers (Altın et al., 2011). Since hot weathers of summer put plants into stress, expected growth is not achieved even with evaporative cooling and fertilizations (Gökkuş, 1989). Therefore, in grasslands established with cool season species, the greatest biomass is observed in spring and autumn.

The best quality of single-sown $L$. perenne plots was attributed to genetic characteristics and this plant being well-adapted to grasslands. Since cool season species exhibit their best growth and development in spring and autumn, they are expected to have greater quality scores in these seasons. But, cold weather of winter and spring of the experimental year recessed plant growth and development. Such a case then yielded greater quality scores in summer instead of spring. Regrowth in autumn again increased the quality scores of grasslands.

Color is the primary quality attribute for grasslands. It is an indicator of agronomic and physiological characteristics and also plays a great role in visually (Kroon and Knops, 1991; Williems et al., 1993). Grassland color is directly related to chlorophyll content of graminae species (Açıkgöz, 1994; Avcioğlu, 1997). Besides chloroplasts, color is also dependent on plant nitrogen, iron, and manganese uptake from the soil and plant water content. Therefore, each graminae species has its specific color tone (Beard, 1973; Açıkgöz, 1994; Avcıoğlu, 1997). Seasonal changes in color characteristics of grasslands continuously increased from spring to autumn. This is because single-sown and mixture grasses exhibited slow growth and development in spring, spent the summer in dormant nature and exhibited the most significant portion of growth and development in autumn. Therefore, the highest color scores were achieved in autumn (Açıkgöz, 1994).

The highest grass width of single-sown plots was attributed to less competition of single-sown plots for water and nutrients than the mixed-sown plots. Single-sown plants had greater plant widths as compared to plant heights. In competitive environments, plants generally have longer, but weaker stems.

Heat requirements of the plants were effective in coverage levels. Since experimented grass species were cool season species, coverage levels were also greater 
in cool seasons (autumn and spring). These plants generally get into dormant season in summers (Altın et al., 2011), thus they have low coverage levels in summers.

\section{Conclusions}

In this study, carried out in Çanakkale province, seasonal (spring, summer and autumn) performance of single-sown Lolium perenne and mixtures with Festuca arundinacea, F. ovina, F. rubra commutata, F. rubra rubra, F. rubra trichophylla and Poa pratensis have been investigated. Present findings revealed increasing fresh and dry biomass in spring and autumn and decreasing values in summer. Grass quality was ordered as autumn $>$ summer $>$ spring and the highest values were observed in singlesown plots. Grass colors increased with increasing number of species in mixtures. Grass quality did not change significantly with the seasons. The darkest grass color was observed in autumn. While grass widths did not change significantly with the seasons, but decreased with increasing number of species in mixtures. The highest grass coverage was attained in autumn. It was concluded based on present findings that single-sown L. perenne plots yielded the highest biomass values and quality attributes.

Acknowledgements. This paper is a part of the doctorate dissertation of Mr. Selçuk Birer's entitled, "The Effects of Chewing in Different Grass Mixtures on Plant Growth and Grass Quality."

\section{REFERENCES}

[1] Açıkgöz, E. (1994): Çim Alanlar Yapım ve Bakım Tekniği. - Uludağ Üniversitesi Ziraat Fakültesi, Bursa.

[2] Altın, M., Gökkuş, A., Koç, A. (2011): Çayır ve Mera Yönetimi (2. Cilt). - Tarım ve Köyişleri Bakanlığı, Tarımsal Üretim ve Geliştirme Genel Müdürlüğü, Ankara.

[3] Avcıŏlu, R. (1997): Çim Tekniği, Yeşil Alanların Ekimi, Dikimi ve Bakımı. - Ege Üniversitesi Ziraat Fakültesi, Tarla Bitkileri Anabilim Dalı, Bornova-İzmir.

[4] Beard, J. B. (1973): Turfgrass Science and Culture. - Prentice Hall, Englewood Cliffs, NJ.

[5] Düzgüneş, O., Kesici, T., Kavuncu, O., Gürbüz, F. (1987): Araştırma ve Deneme Metotları (İstatistik Metotları-II). - A. Ü. Zir. Fak. Yayınları, 1021/295.

[6] Goatley, J. M., Maddox, V. L., Watkins, R. M. (1996): Growth regulation of bahiagrass (Paspalum notatum Fluegge) with imazaquin and AC 263,222. - HortScience 31(3): 396399.

[7] Gökkuş, A. (1989): Gübreleme, sulama ve otlatma uygulamalarının Erzurum ovasındaki çayırların kuru ot ve ham protein verimlerine etkileri. - DOĞA Tu. Tar. ve Orm. Dergisi 13(3b): 1002-1020.

[8] Kroon, H. D., Knops, J. (1991): Habitat exploration through morphological plasticity in two chalk grassland perennials. - Herbage Abst. 61: 8.

[9] Mehall, B. J., Hull, R. J., Skogley, C. R. (1983): Cultivar variation in Kentucky bluegrass: P and K nutritional facts. - Argon. J. 75: 767-772.

[10] Miller, D. A. (1984): Forage Crops. - McGraw Hill Book Co., New York.

[11] Oral, N., Açıkgöz, E. (2002): Çim Alanlar için Tohum Karışımları. - TMMOB Ziraat Mühendisleri Odası Bursa Şubesi Başkanlığı Yayınları, 1.

[12] Önder, S., Polat, A. (2012): Kentsel açık-yeşil alanların kent yaşamındaki yeri ve önemi. - Kentsel Peyzaj Alanlarının Oluşumu ve Bakım Esasları Semineri, Konya, pp. 73-96. 
[13] Sills, M. J., Carrow, R. N. (1983): Turfgrass growth, N use and water use under soil compaction and $\mathrm{N}$ fertilization. - Argon. J. 75: 488-492.

[14] Sözen, N., Halepoğlu, N., Şahin, Ş. (1991): Ülkemizde süs fidancıllğının durumu ve pazar açısından karşılaşılan sorunlar. - Türkiye I. Fidancılık Sempozyumu, pp. 411-419.

[15] Spangenberg, B. G., Fermanian, T. W., Wehner, D. V. (1986): Valuation of liquidapplied nitrogen fertilizers on Kentucky bluegrass turf. - Argon. J. 78: 1002-1006.

[16] Wehner, D. J., Haley, J. E., Martin, D. L. (1988): Late fall fertilization of Kentucky bluegrass. - Argon. J. 80: 466-471.

[17] Williems, J. H., Peet, K. R., B1k, L. (1993): Changes in chalk grassland structure and species richness resulting from selective nutrient additions. - Herb. Abstract 63(7).

\section{APPENDIX}

Photos of the study area
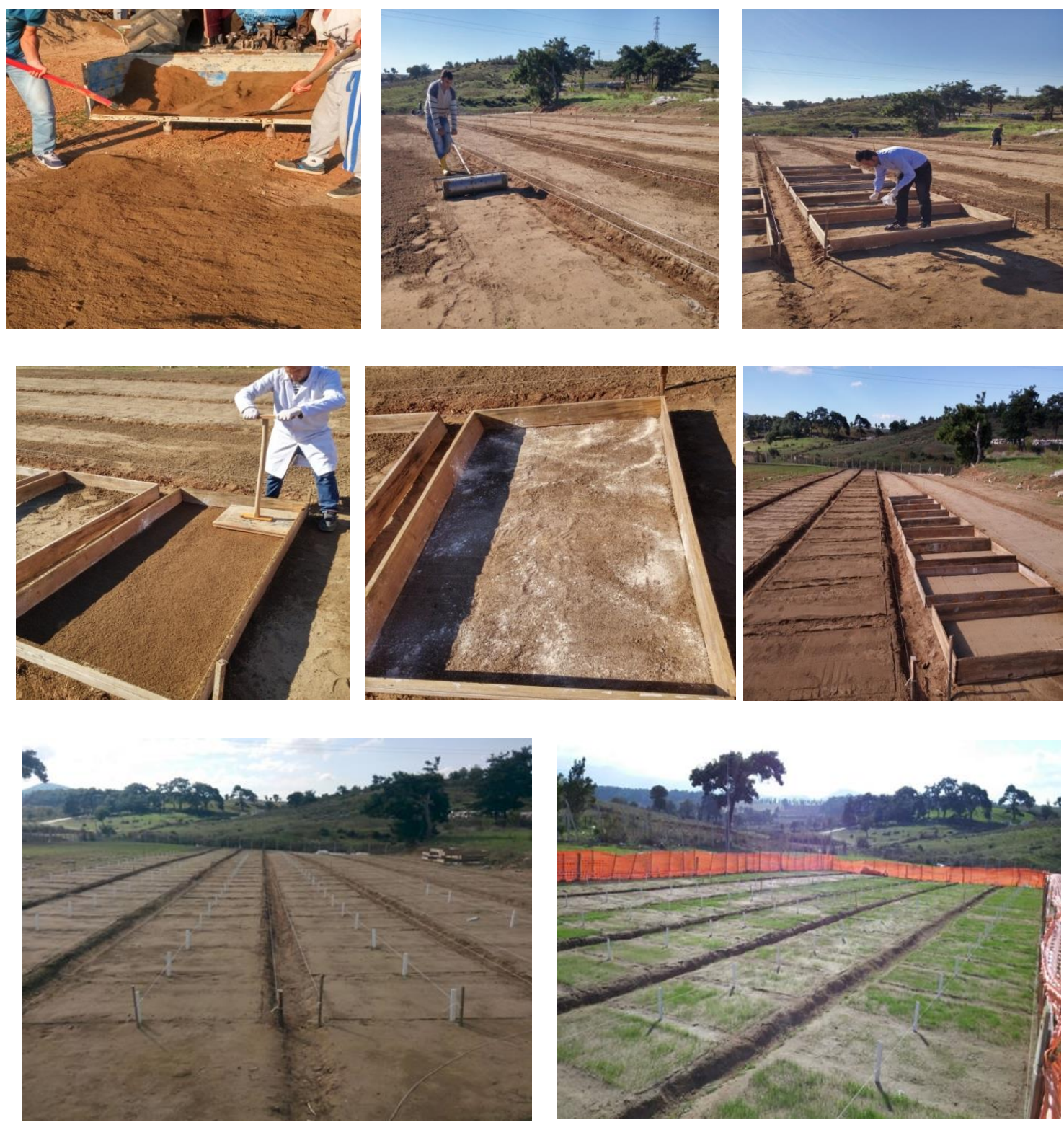

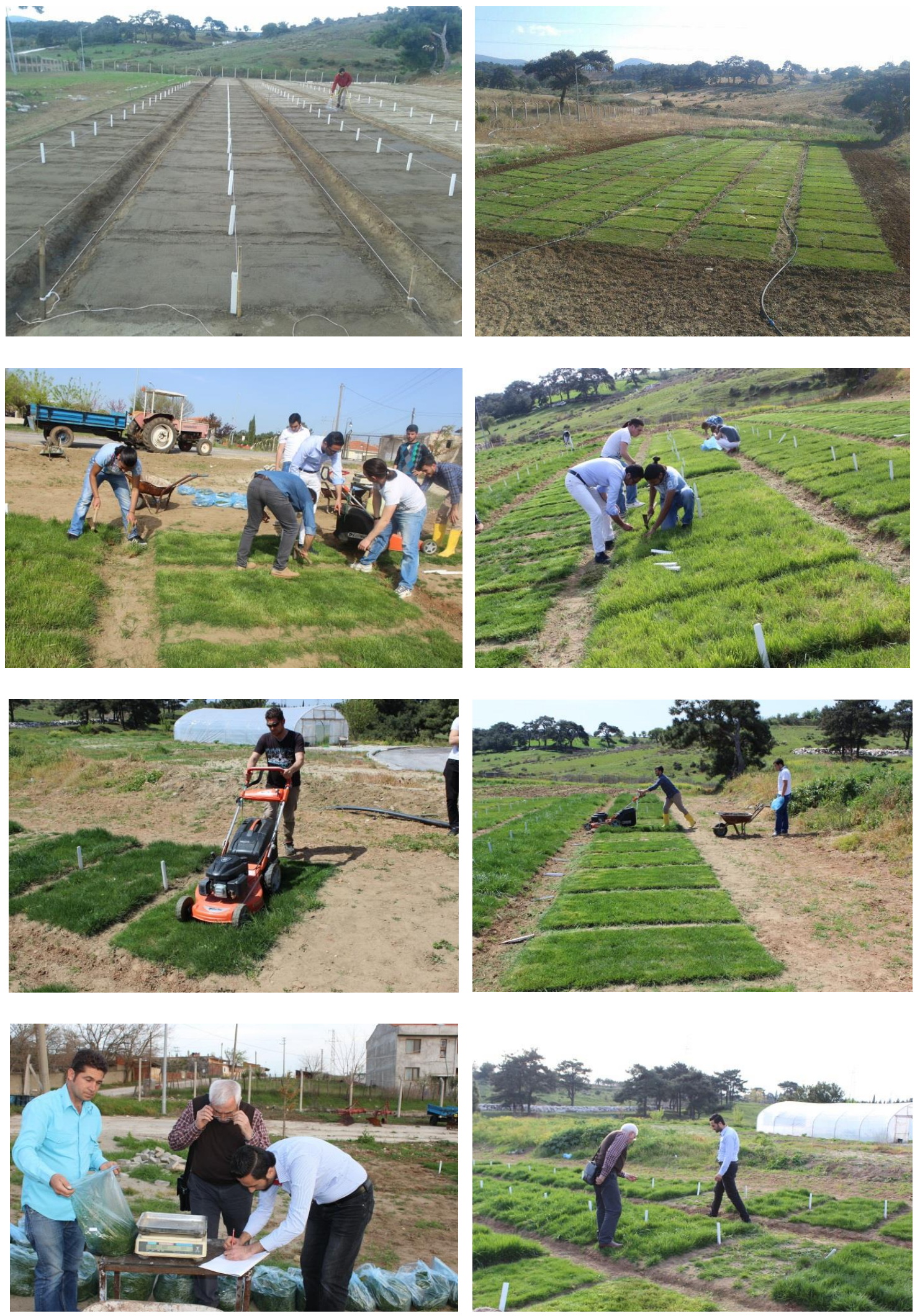